\title{
THE USE OF CHEMSKETCH TO INCREASE STUDENT LEARNING OUTCOMES AND MOTIVATION IN LEARNING HYDROCARBONS
}

\author{
Jesi Jecsen Pongkendek*, Dewi Natalia Marpaung, Evi Nurvitasari, John Yoro Parlindungan \\ Fakultas Keguruan dan Ilmu Pendidikan, Universitas Musamus, Merauke, Indonesia
}

\begin{abstract}
Learning motivation is an encouragement in students to be able to learn well, add skills and provide learning experiences. High learning motivation will improve learning outcomes. This research is quantitative research to determine students' learning motivation, student learning outcomes, and the relationship between learning motivation and learning outcomes in learning chemistry on Hydrocarbon material with the application of Chemsketch media. The research was conducted at SMAN 2 Merauke in Class XI IPA 1 with 28 students. The sampling technique used is simple random sampling. The research data was obtained by using learning outcomes tests and learning motivation questionnaires. The research data were analyzed descriptively and the results obtained were: (1) student learning outcomes with an average score of 81,86 with 25 students passed the test and 3 students not past the test, (2) students' learning motivation with an average score of 80, 86 with 11 people in the very high category and 17 people in the high category. Followed by quantitative data analysis to test the linearity of the data, the normality of the data, and the correlation between learning motivation and learning outcomes with the Pearson bivariate correlation test. After analyzing the results obtained that (1) there is a linear and significant relationship, (2) the data is normally distributed, (3) there is a significant relationship between learning motivation and learning outcomes.
\end{abstract}

Keywords: Learning motivation; Learning outcomes; Chemsketch

\footnotetext{
${ }^{*}$ Corresponding author: Fakultas Keguruan dan Ilmu Pendidikan, Universitas Musamus, Merauke, Indonesia. Email: pongkendek@unmus.ac.id

ISSN 2528-6536 (print)/ISSN 2579-5945 (online) @2021 J-PEK
} 


\section{INTRODUCTION}

Education is one of the most important factors in improving human resources (Sitepu \& Simanjuntak, 2018). Self-development and student skills are carried out in the education process. The role of educators is vital in developing students' abilities. Educators are required to provide good learning conditions for students to achieve certain skills that must be learned by students (Marpaung, 2019). Learning success of students is determined by the learning strategies created by the teacher. In addition, teaching methods need to be improved so that they can keep up with the times (Betaubun et al., 2020)

Learning is a process or effort made by each individual to obtain behavioral changes in the form of knowledge, attitudes, skills, and positive values obtained during the learning process, this process of behavior change as a result of one's interactions with their environment (Azrai et al., 2017) (Septryanesti \& Lazulva, 2019). Learning outcomes are changes in student behavior that can be measured due to learning in the form of skills, knowledge, and values achieved in learning (Lumentut et al., 2017) (Pongkendek et al., 2019)

Learning motivation is one of the internal factors that can affect learning achievement. Motivation is a driving force for students to do something to achieve goals. Learning becomes effective with the motivation for students to learn and make high learning achievements (Mediawati, 2010). Learning motivation is an encouragement in students to be able to learn well, add skills and provide learning experiences (Pongkendek et al., 2019).

The role of motivation for students are: (1) as a psychic mobilizer in the students' self-interest so that it creates a desire to learn and also guarantees the learning process well, (2) as an encouragement and also a sense of joy for students so as to generate energy for learning (Palittin et al., 2019). Motivation has a very big role on student learning outcomes, because with the motivation can foster interest and student learning activities so that the quality of student learning outcomes become better (Mbosisi \& Mustapa, 2018). Some ways to generate motivation are through various ways of learning, holding a repetition of information, providing new stimuli, and evaluating learning (Yuliany, 2018)

Chemistry is one of the subjects that is difficult for students to understand, so teachers need to design creative learning that can make students understand the subject matter. The difficulty of learning chemistry from students is due to the presentation of learning material that does not involve the activities of students and emphasizes more on things that are theoretical (Harta et al., 2020). The teacher needs supporting tools in explaining learning material that is appropriate to 
certain topics (Marpaung et al., 2019). Chemistry learning emphasizes the way students master concepts and not memorize each other's facts. Chemical concepts have a high level of generalization and abstraction that causes students to experience difficulties in mastering learning material (Farid \& Nurhayati, 2014). In chemistry learning, students need to see a real picture of the learning material presented so that it will make it easier for students to understand the learning concepts presented (Iqbal \& Tarigan, 2019)

One of the materials in chemistry lessons in high school is hydrocarbons. The characteristics of hydrocarbon material are as follows: (1) hydrocarbon material has a high level of abstraction because it involves the shape, nature, and character of the invisible carbon atom; (2) the hydrocarbon material contains many and varied terms and facts that students must memorize; (3) terms in hydrocarbon material are generally in the form of compound names, foreign to students; and (4) hydrocarbon material is a solid material, so it takes a longer time to deliver material in class. Hydrocarbons are the basis of chemical materials that are closely related to everyday life, which are useful for learning more chemical concepts. Without a good understanding, students will find it difficult to understand the next material at a higher level (Nazalin \& Muhtadi, 2016).

The results of observations made at SMAN 2 Merauke include: (1) the atmosphere of learning in the classroom is too monotonous so students are less uptake, (2) some students are not active in learning, (3) some students cannot focus on learning even just playing in class, (4) student learning outcomes in learning chemistry are low. Students are less interested and not active in learning because learning is teacher centered. The teacher only uses marker and whiteboard tools to write molecular formulas and draw them on the board. The teacher's skills in writing chemical formulas are very necessary so students are interested so that learning is not monotonous and boring. Teachers must use appropriate learning media to motivate students to do learning by using the right media (Yanda \& Safitri, 2018)

Variations in learning methods, good learning behavior, a conducive learning climate and interesting learning media can overcome student learning difficulties (Handhika, 2012). In simplifying the delivery of learning materials to students required appropriate learning media.

Learning media are all things that can be used as intermediaries to convey messages (learning material) from educators (communicators) to students (communicants) (Linda et al., 2017). The application of appropriate learning media, will be able to increase student learning motivation in learning chemistry and satisfying learning outcomes (Sitepu, 2016). Another benefit of learning 

media is that it can arouse student motivation in learning, optimize teaching and learning processes, as well as a means of assisting teachers in delivering lessons (Indriyanti et al., 2020)

Some learning media that can be used in learning Chemistry especially Hydrocarbons include ChemDB, Chemical Reagent Calculator, Chemsketch, Symbols and Equations, and Atom Builder and Atoms. Visualization of chemical structures and atomic models is used by Chemsketch to make it easier for students to understand hydrocarbon material (Raiyn \& Rayan, 2015)

Chemsketch is a learning software from ACD / Labs that can be used to draw molecular structures, including organic molecules, organometallic compounds, polymers, and Markush structures. Chemsketch can also be used for: (1) calculation of physical and chemical properties, (2) making 2D and 3D structures, (3) making chemical names of chemical structures, molecular formulas and molecular weights of chemical structures.

Chemsketch is an application often used by chemists to write down chemical structures. Chemsketch as a computer based learning media program is a modeling and visualization of the structure of chemical compounds. The use of Chemsketch as a learning medium has the ability to change 2-dimensional structures into 3 dimensions so that it makes it easier for students to understand concepts concretely (Utami et al., 2017).

Research conducted by (Harahap \& Siregar, 2019) shows that there is a significant effect of the STAD type Cooperative Learning model with Chemschetch media on student learning outcomes. Another study by (Utami et al., 2017) concluded that Chemsketch in writing chemical structures on recitation methods had a positive effect on student learning outcomes.

This research was conducted to use Chemsketch in learning the Hydrocarbon material by looking at the motivation and learning outcomes of students after participating in the lesson, as well as the relationship between motivation and learning outcomes of chemistry after the use of Chemsketch.

\section{METHODS}

This research uses a quantitative approach and is carried out at SMAN 2 Merauke. This research was conducted in class XI IPA 1 with a total of 28 students who were determined using simple random sampling. Simple random sampling is a sampling method with all objects or elements of the population having an equal chance of being selected as a sample.

The research data were obtained from learning achievement tests and motivation questionnaires. The learning achievement test instrument and the learning motivation questionnaire used were validated by 2 experts. The minimum completeness criteria of students in chemistry learning is 75 . 
The data obtained in the form of student motivation, are analyzed and made in several categories. According to (Hamalik, 2001) motivation categorization namely:

Table 1. Categorizing learning motivation

\begin{tabular}{cc}
\hline Score interval & Category \\
\hline $85-100$ & Very high \\
$70-84$ & High \\
$55-69$ & Medium \\
$40-54$ & Low \\
$0-40$ & Very low \\
\hline
\end{tabular}

The data analysis technique in this study was Pearson bivariate correlation analysis, to determine the relationship between learning outcomes and student motivation with the application of Chemsketch media in Hydrocarbons learning. Before the correlation test, the prerequisite test is done with linearity test and data normality test. The data analysis process was carried out with the help of SPSS 16.0 software.

\section{RESULT AND DISCUSSION}

This research was conducted using Chemsketch media in Hydrocarbons learning. In the implementation of learning, it was seen that students were so enthusiastic about learning the learning materials carried out using Chemsketch media. The depiction of Hydrocarbon molecules in $2 \mathrm{D}$ and $3 \mathrm{D}$ becomes very interesting for students. After carrying out the learning carried out the learning outcomes test. After that, students fill out a student motivation questionnaire.

\section{Learning outcomes}

Table 2. Learning outcomes

\begin{tabular}{cc}
\hline Statistics & Statistical score \\
\hline Students total & 28 student \\
Maximum score & 100 \\
Highest score & 92 \\
Lowest score & 70 \\
Average score & 81,86 \\
Standard deviation & 5,097 \\
Past the test & 25 student \\
Not past the test & 3 student \\
\hline
\end{tabular}

Based on the data on student learning outcomes, it can be seen that the learning outcomes of students after the application of Chemsketch media are very good with an average score of 81.86, the lowest score is 70 and the highest is 92 , the standard deviation is 5.097 , and the number of 
Iesi Jecsen Pongkendek*. Dewi Natalia Marpaung, Evi Nurvitasari, John Yoro Parlindungan students who have past the test 25 people $(89.29 \%)$ and students who did not past the test 3 people $(10.71 \%)$.

\section{Learning motivation}

Table 3. Learning motivation

\begin{tabular}{cc}
\hline Statistics & Statistical score \\
\hline Students total & 28 student \\
Maximum score & 100 \\
Highest score & 95 \\
Lowest score & 71 \\
Average score & 80,86 \\
Standard deviation & 6,485 \\
Very high learning motivation & 11 student \\
High learning motivation & 17 student \\
\hline
\end{tabular}

Based on student learning motivation data, it can be seen that students' learning motivation after the application of Chemsketch media is in the high category with an average value of 80.86 , the lowest value of 71 and the highest 95, standard deviation of 6.485 , and 11 students who have very high learning motivation (40\%) and 17 students (60\%).

\section{Relation between learning motivation and learning outcomes}

In the Pearson bivariate correlation test, the analysis prerequisite is that the data must be linear and normal. If it does not meet the analysis prerequisite test, then parametric testing cannot be carried out. Therefore, before carrying out the correlation test, a linearity test and a normality test of the data are carried out

\section{Linearity test}

This linearity test is processed using the SPSS16 program. In the test that needs to be seen is the value of Deviation from Linearity Sig., if the value of Deviation from Linearity Sig. $>0.05$, then there is a significant linear relationship between the two variables. On the other hand, if the Deviation from Linearity Sig. $<0.05$, then there is no significant linear relationship between the two variables. From the output value Deviation from Linearity Sig. is $0.508>0.05$. So it can be concluded that there is a significant linear relationship between the variables of learning motivation $(\mathrm{X})$ and learning outcomes $(\mathrm{Y})$.

\section{Normality test}

The normality test is carried out to see whether the data is normally distributed. In testing what needs to be seen is the Sig value. from Shapiro Wilk because the research data sample is less than 50. If the value of Shapiro Wilk Sig. $>0.05$ means that the data is normally distributed. From the 
output value of Shapiro Wilk Sig. For Learning Motivation $(\mathrm{X})$ is $0.195>0.05$ means the data is normally distributed. The output value of Shapiro Wilk Sig. For Learning Outcomes (Y) is 0.930 $>0.05$ means the data is normally distributed

\section{Correlation test}

After the prerequisite tests: (1) the linearity test shows that there is a linear and significant relationship between learning motivation and learning outcomes, (2) the data normality test shows data on learning motivation and normally distributed learning outcomes. Then the test can continue to test the correlation.

The relationship between learning motivation and student learning outcomes was tested with the Pearson bivariate correlation test. If the value of sig. (2-tailed) $<0.05$, then there is a significant correlation between the variables of learning motivation and student learning outcomes. From the test output with SPSS obtained sig data. (2-tailed) of $0.006<0.05$, meaning that there is a correlation between learning motivation and student learning outcomes. This shows that if students' learning motivation increases, it can also improve student learning outcomes.

Student learning achievement is influenced by various factors, one of which is learning motivation. Learning motivation is one of the factors that determine the effectiveness of a learning. Learning motivation is the overall driving force in students that causes learning activities. Learning motivation that can ensure the continuity of learning activities, and which provides direction to learning activities, so that the goals desired by students can be achieved. Students who have a strong learning motivation will have a lot of energy to follow the learning process (Sardiman, 2011). This is in accordance with the results of research conducted by Abidin and Ijrah (Abidin \& Ijrah, 2018) which states that the relationship between learning motivation and learning outcomes is positive, which means that the higher the learning motivation, the higher the learning outcomes achieved by students, and vice versa the lower the learning outcomes. student learning motivation, the lower the learning outcomes achieved by students. This shows that learning motivation plays an important role in achieving better learning outcomes. This is because learning motivation is one of the factors that affect student learning outcomes.

Students have high learning motivation after following the learning process using Chemsketch. High student learning motivation can be seen from the persistence of students to follow the procedures in the given module and are happy to do the exercises given. When students have high learning motivation, this will encourage students to be actively involved in learning and be able to carry out learning activities with full confidence and responsibility compared to students with low 
Iesi Jecsen Pongkendek*. Dewi Natalia Marpaung, Evi Nurvitasari, John Yoro Parlindungan learning motivation. In the learning process students will find various problems faced, so a student must have high enthusiasm and motivation in learning in order to be able to achieve the goals to be achieved. High learning motivation is expected to improve student learning outcomes.

Based on the results of data analysis in tables 2 and 3, it can be seen that the learning outcomes and learning motivation of students after participating in learning with Chemsketch is high. In table 6 the correlation test between learning motivation and learning outcomes shows that there is a significant correlation between learning motivation and learning outcomes. This shows that if students have high motivation, the learning outcomes will also be high.

Through this research, it can be recommended to chemistry teachers that the application of Chemsketch media in Hydrocarbon learning is very good to apply because: (1) student motivation is high, (2) high learning outcomes, (3) there is a significant relationship between learning motivation and results learn.

\section{CONCLUSSION}

The implementation of chemistry learning on Hydrocarbons material with Chemsketch Media shows the value of learning outcomes with an average of 81.86 and learning motivation with an average value of 80.86 is in the high category. This shows that students' learning motivation and learning outcomes are high by applying Chemsketch in hydrocarbon learning. Based on quantitative data analysis with SPSS 16.0, the results showed that there was a significant relationship between learning motivation and learning outcomes. This shows that by increasing students' learning motivation, it can also improve student learning outcomes, so that in learning it is expected that teachers can apply variations of learning media so that students' learning motivation can grow and can also improve student learning outcomes.

\section{REFERENCES}

Abidin, Z., \& Ijrah, S. (2018). Hubungan Motivasi Belajar dengan Hasil Belajar Pada Siswa Kelas V SD Negeri Gugus IV Kecamatan Banuhamou Kabupaten Agam. Jurnal Inovasi Pendidikan dan Pembelajaran Sekolah Dasar, 2(2), 21-29.

Azrai, E. P., Ernawati, E., \& Sulistianingrum, G. (2017). Pengaruh Gaya Belajar David Kolb (Diverger, Assimilator, Converger, Accommodator) Terhadap Hasil Belajar Siswa Pada Materi Pencemaran Lingkungan. Biosfer: Jurnal Pendidikan Biologi, 10(1), 9-16. https://doi.org/10.21009/biosferjpb.10-1.2 Betaubun, M., Asmaningrum, H. P., \& Nasrawati. (2020). Analisis Kebutuhan E-book Interaktif Bilingual Etnokimia dengan Pendekatan Konstruktivisme. Magistra, 7(1), 10-22. 
Farid, A., \& Nurhayati, S. (2014). Pengaruh Penerapan Strategi React Terhadap Hasil Belajar Kimia Siswa Kelas XI. Chemistry in Education, 3(1).

Hamalik, O. (2001). Teknik Pengukuran dan Evaluasi Pendidikan. CV. Mandar Maju.

Handhika, J. (2012). Efektivitas Media Pembelajaran IM3 Ditinjau dari Motivasi Belajar. Jumal Pendidikan IPA Indonesia, 1(2), 109-114. https://doi.org/10.15294/jpii.v1i2.2127

Harahap, S. N., \& Siregar, M. F. (2019). Pengaruh Model Pembelajaran Dengan Mengintegrasikan Strategi Pembelajaran Cooperative Learning Tipe STAD Dengan Media Chemsketch Terhadap Hasil Belajar Siswa. Cyberspace: Jurnal Pendidikan Teknologi Informasi, 3(1), 1-7. https://doi.org/10.1017/CBO9781107415324.004

Harta, J., Limbong, S. A., \& Waruwu, E. E. (2020). Pengembangan Media Pembelajaran Asam Basa Inovatif Berbasis Green Labyrinth untuk SMA. J-PEK Jurnal Pembelajaran Kimia), 5(1), 17-31. https://doi.org/10.17977/um026v5i12020p017

Indriyanti, N. Y., Widisatuti, A., Suryadi, B. U., \& Hasanah, N. (2020). Pemberdayaan Guru Kimia Melalui Produksi Media Pembelajaran Berbasis Aplikasi Chemsketch. Jurnal Bakti Saintek, 4(1), 23-26. https://doi.org/10.14421/jbs.1566

Iqbal, M., \& Tarigan, I. L. (2019). Pengaruh Model Pembelajaran Siklus Belajar 5E Menggunakan Media Animasi Terhadap Aktivitas Belajar Dan Hasil Belajar Siswa SMA Kelas XI Pada Materi Hidrolisis Garam. J-PEK Jurnal Pembelajaran Kimia), 4(1), 31-38. https://doi.org/10.17977/um026v4i12019p031

Linda, R., Herdini, \& Rahmaputri, Z. (2017). Multimedia interaktif berbasis autoplay media studio 8 untuk mata pelajaran kimia pokok bahasan laju reaksi untuk kelas XI SMA/MA. Jurnal Pendidikan Kimia, 9(3), $347-351$.

Lumentut, R. S., Said, I., \& Mustapa, K. (2017). Pengaruh Model Pembelajaran Guided Inquiry dengan Mind Map terhadap Hasil Belajar dan Motivasi Siswa pada Materi Redoks di Kelas X SMA Negeri 5 Palu. Jurnal Akademika Kimia, 6(2), 113-118. https://doi.org/10.22487/j24775185.2017.v6.i2.9242

Marpaung, D. N., Siregar, L. F., \& Pongkendek, J. J. (2019). The development of innovative learning material integrated with environmental activities to improve student learning outcomes on electrolyte and nonelectrolyte solution. IOP Conference Series: Earth and Environmental Science, 343(1). https://doi.org/10.1088/1755-1315/343/1/012218

Marpaung, Dewi Natalia. (2019). Implementation of Active and Creative Learning Through Multimedia on the Teaching of Solubility and Solubility Product. Journal of Basic and Applied Scientific Research, 9(6), 4246.

Mbosisi, S. B., \& Mustapa, K. (2018). Pengaruh Penerapan Model Pembelajaran Kooperatif Tipe Teams Games Tournament Berbasis Scramble Terhadap Motivasi dan Hasil Belajar Siswa SMA Kristen GPID Palu. Jurnal Akademika Kimia, 7(1), 36-40.

Mediawati, E. (2010). Pengaruh Motivasi Belajar Mahasiswa Dan Kompetensi Dosen Terhadap Prestasi 
Iesi Tecsen Pongkendek*. Dewi Natalia Marpaung, Evi Nurvitasari, John Yoro Parlindungan Belajar. Dinamika Pendidikan, 5(2), 134-146. https://doi.org/10.15294/dp.v5i2.4922

Nazalin, N., \& Muhtadi, A. (2016). Pengembangan Multimedia Interaktif Pembelajaran Kimia Pada Materi Hidrokarbon Untuk Siswa Kelas XI SMA. Jurnal Inovasi Teknologi Pendidikan, 3(2), 221. https://doi.org/10.21831/jitp.v3i2.7359

Novita Yanda, S., \& Safitri, Y. (2018). The Effect of Using E-learning Material on Hydrocarbon Chapter to Improve Students' Achievement Motivation in Learning Chemistry. ICESST 2018, 843-847. https://doi.org/10.29210/20181122

Palittin, I. D., Wolo, W., \& Purwanty, R. (2019). Hubungan Motivasi Belajar dengan Hasil Belajar Siswa. Magistra, 6(2), 110-118.

Pongkendek, J. J., Parlindungan, J. Y., \& Marpaung, D. N. (2019). Effectiveness of the Application of Team Games Tournament Cooperative Learning Model (TGT) to Improve Learning Outcomes of Students of Class XI Science 1 SMA Frater Makassar in the Principal Material of Salt Hydrolysis. IOP Conference Series: Earth and Environmental Science, 343(1). https://doi.org/10.1088/1755-1315/343/1/012228

Pongkendek, Jesi Jecsen, Marpaung, D. N., \& Siregar, L. F. (2019). Analisis Motivasi Belajar Siswa Dengan Penerapan Model Pembelajaran Kooperatif Tipe Team Games Tournament. Musamus Journal of Science Education, 2(1), 31-38. https://doi.org/10.35724/mjose.v2i1.2243

Raiyn, J., \& Rayan, A. (2015). How Chemicals' Drawing and Modeling Improve Chemistry Teaching in Colleges of Education. World Journal of Chemical Education, 3(1), 1-4. https://doi.org/10.12691/wjce$3-1-1$

Sardiman. (2011). Interaksi dan Motivasi Belajar Mengajar. PT. Raja Grafindo.

Septryanesti, N., \& Lazulva, L. (2019). Desain Dan Uji Coba E-Modul Pembelajaran Kimia Berbasis Blog Pada Materi Hidrokarbon. JTK Jurnal Tadris Kimiya), 4(2), 202-215. https://doi.org/10.15575/jtk.v4i2.5659

Sitepu, C. P. K. (2016). Pengaruh Pemanfaatan Media Chemsketch Dalam Pembelajaran Yang Menggunakan Metode Resitasi Terhadap Motivasi Dan Hasil Belajar Kimia Di SMK Kelas XI. Jumal Ilmiah “INTEGRITAS,” 2(1).

Sitepu, C., \& Simanjuntak, R. (2018). Upaya Meningkatkan Hasil Belajar Mahasiswa Pada Materi Bentuk Molekul Dengan Model Pembelajaran Kooperatif Tipe Think Pair Share (TPS) Berbantuan Media Physics Education Technology (PhET) Dan Chemsketch. JURNAL Sulub Pendidikan FKIP-UHN, 5(2), 36-47. https://doi.org/10.1017/CBO9781107415324.004

Utami, H. H., Sulfikar, \& Anwar, M. (2017). Pengaruh Chemsketch Dalam Penulisan Struktur Kimia Pada Merode Resitasi Terhadap Hasil Belajar Siswa (Materi Pokok Ikatan Kimia). Jurnal Penelitian Pendidikan INSANI, Vol.20(No.2), 96-100.

Yuliany, N. (2018). Relationship Between Learning Motivation to Learning Result Mathematics Students. AULADUNA, 5(2), 126-137. 